\title{
Functional Nature of Life-long Learning in Raising Living Standard in Inclusive Society
}

\author{
M.A. Isaikina ${ }^{1, *}$, E.A. Maksimova ${ }^{1}$, E.V. Martynova ${ }^{1}$ and N.V. Shelyakhina ${ }^{1}$ \\ "Corresponding author: mariya-isaikina@mail.ru \\ ${ }^{1}$ Saratov Socio-Economic Institute of Plekhanov Russian University of Economics, Saratov, Russia
}

\begin{abstract}
The structural-functional analysis of the socio-cultural peculiarities of implementing inclusive policy in educational process in Russia is carried out. The issues of the inclusive approach introduction in higher education are touched upon. The main indicators of the living standard in the country including the level and accessibility of education are listed, interrelation of the living standard and quality of education are emphasized. The history of development and the difficulties of implementing inclusive education in Russia are considered. In particular, the historical, organizational, content and socio-economic peculiarities of inclusive education development in Russia are conceptualized. The importance of the inclusion being one of the main principles of the modern society is underlined. The main reasons for the difficulties in implementing inclusive education in Russia are indicated. Some of them are the lack of the necessary theoretical and methodological research as well as material and technical support. One of the main objectives in the implementation of inclusive education is a special organization of educational process including social integration and psychological adaptation of students with disabilities. A special role is given to the teacher who should be able to organize the educational process effectively providing equal opportunities for all its participants. In conclusion, possible solutions of the problems connecting with implementing an inclusive approach in higher education in Russia are outlined taking into account the peculiarities of its development.
\end{abstract}

Keywords: inclusion, education, living standard, the peculiarities of inclusive policy.

\section{Introduction}

The realization of inclusive approach in education is the indicator of the life quality of a nation and all living environment availability for all community members to the same extent $[1,2]$. According to United Nations, the quality of education is considered to be one of the basic indicators of a nation's well-being alongside with life expectancy and income per capita in the country. The Deputy Secretary-General made a speech to leaders of different countries in June 2017 in the United Nations Headquarters in New York. She stated that educational level improvement would lead to the raise in nations' well-being. As the quality of education determines the living standard of a country as a whole, so we first appeal to the definition of the notion of the life quality level in a country.

\section{Problem Statement}

Life quality of a nation is regarded as the satisfaction of human needs in terms of material, spiritual and social points of view. Life quality as a general socio-economic category does not only include the level of material wealth consumption but also the meeting of spiritual needs, health issues, life expectancy, environmental conditions, moral and psychological climate and mental comfort [3]. The low living standard makes people face unsatisfactory quality of their lives in spite of their types of activity and personal life factors. The person tends to get the higher level of education, career prospects and social integration. There are some life level indicators among which are personal income (subsistence minimum rate, salary and pension rate), quality of housing, food and clothes, health care and social services as well as education, environment and demographic tendency [4]. These indicators may be recognized as the basic ones. Living standard and life quality are characterized by the production of 1 goods per capita in domestic industries.

The social policy of the country should be worked out in such a way that it makes it possible to equalize life quality and living standards opportunities for all social groups. Being the key issues of government policy the life quality increase is realized in four priority areas and regulated by National projects known as "Public Health", "Education", "Housing", "Development of Agricultural Sector". These priority areas are aimed at establishing and developing the human capital, educated and healthy population. It is marked out that in Post-Soviet Russia there were economic obstacles for getting qualified education and training in the Higher Education Establishments because of tuition fee raising in particular. The number of state-financed student places is being reduced and the personal income is becoming the most significant asset for entering the institution. It leads to stratification of people on the base of their living standard [5].

The expected results of educational services quality raise in the sphere of higher education, professional training and lifelong education are highlighted in the Decree "Development of Education" made by the Government of the Russian 
Federation. Issues connected with human rights of people with disabilities are reflected in different papers such as United Nations Convention on the Rights of Persons with Disabilities that was ratified by the Russian Federation. The Convention reads that Inclusive education system and lifelong learning should be ensured at all levels. The Convention says that a person with disabilities avoids entire and effective participation in the community life not only because of his limitations but also because of barriers existing in the society. The Convention Ratification marks the intention of the Government to create the material basis for a fulfilling life for people with disabilities as the integral part of the society [6].

\section{Research Questions}

According to the Resolution of United Nations General Assembly "Transforming our World: the 2030 Agenda for Sustainable Development" the Sustainable Development Goals were set. There are 17 of them including health and well-being, gender equality, climate action, economic growth and others. The fourth goal of the sustainable development is the quality education that means "obtaining the quality education is the foundation to improving people's lives and sustainable development". Access to inclusive education can help in improving the quality of life as well as promotion of lifelong education for all people. Great success was reached in expanding the access to education at different levels. However, more decisive measures are necessary to fulfill the goals of providing total education [7]. Comparable indicators for monitoring and progress assessment should be elaborated for future generations to evaluate the goal achievement [8].

The United Nations report concerning the individual development contains the information about the Human Development Index that is annually calculated by the experts of the UN Development Program together with independent experts. Independent experts use different statistical data from national establishments and worldwide research organizations in their work. Human Development Index was formulated by the group of economists headed by a Pakistani economist Mahbub ul-Hag and since 1990 it has been used in the United Nations annual human development report. This indicator helps to evaluate the country achievements with regard to lifetime, education and income in three main directions as health and longevity (the indicators of the expected life expectancy), access to education (the literacy level of adults in a country and gross education coverage of population), respectable level of living (the amount of Gross National Product per capita measured in US dollars at parity of purchasing power) [9].

However, we cannot speak about the complete accessibility of the educational environment in the Russian society. It is connected with peculiarities of inclusive processes in Russia. First, the lack of appropriate theoretical and methodical research on the persons with disabilities as participants of professional education process should be mentioned. There existed no support system of professional education for people with disabilities that would be coherent, scientific and based on methodological principles [10]. Purposes, objectives, content, forms and methods of support system are not widely used in scientific papers. The study of different aspects of support system in higher education for learners with disabilities is of necessity. But the learning process should be organized in homogeneous training groups or in heterogeneous ones.

Learners with disabilities are recommended to get higher education being involved in distance, individual or online educational process. It seems to be a reasonable and an effective solution as digital technologies give a perfect opportunity for data transferring and its getting, for professional competence and many various kinds of activity realization. They help to reach all students and to use rare teaching resources, namely, to take advantage from the most valuable teachers for the most diverse audience [11]. For many persons with disabilities it is the only way to be educated. In spite of obvious advantages, it is noteworthy that being organized in such a manner the distance education reserves segregation that is fundamentally contrary to the idea of inclusion. The general principle of inclusion is the true involving of persons with disabilities in active public life of the community and adaptation of educational and social environment to abilities of every learner. The distance education eliminates the persons with disabilities from the total education process, limits their social experience and reduces inclusive process.

\section{Purpose of the Study}

The purpose of the study conducted is to analyze the background of the gaps in inclusive education obvious in Russia. The problem is of current interest due to the government policy aimed at raising the living standard in the country. In its essence inclusive approach to professional education is connected with overcoming discrimination and segregation. Moreover the ability of higher education to transform the personality of students for them to be members of the inclusive democratic society is highly appreciated [12]. Accessible educational environment means creating specialized educational resources: the basic educational program aimed at students with special educational needs due to their disabilities. It also presupposes an individual curriculum, means of education and technologies of distance education. Mentally comfortable environment in the educational organization is of importance as well.

However, in practice the requirements mentioned are not identical to their implementation. Introducing the main ideas of inclusive education in the educational practice is accompanied by certain problems and is followed by difficulties in both organization of the educational process and social and psychological integration of people with disabilities. 


\section{Research Methods}

The research is conducted involving scientific methods of participant and non-participant observation and study of the experience gained. It also contains methods of the conceptual and socio-philosophic analysis; procedures of the comparative, structural and functional analysis. Other methods used are content analysis of the legislative regulation and social policy aimed at raising living standard of the population, at improving the quality and accessibility of education both at national and international levels. Qualitative and theoretical analysis of scientific literature to learn about peculiarities in the implementation of inclusive policy in the field of professional education has been carried out.

\section{Findings}

In spite of terminology being innovative (namely "inclusive processes in education"), the practice of educating people with different disabilities has a long history and traditions in Russia.

Russia has always had a compassionate attitude to people with disabilities. Churches and monasteries had shelters where they could get food. However, it was far from being a system of state support of the disabled. First attempts to make care of people with disabilities systematic were taken at the beginning of the XIX century. The first educational establishment for the disabled people was a specialized school for the blind, opened in 1803. Alongside studying arithmetic, reading, writing, students of the school learned primitive crafts: basketwork, woodwork. Unfortunately, the school didn't work long. Due to numerous obstacles V. Gayui, who opened and maintained it, had to leave Russia [13].

The development of the specialized school for the deaf-and-dumb in St. Petersburg was more fortunate, students got general and craft education there [14]. Having being reorganized many times, having changed conditions of its work and affiliation, it still exists today. It is worth understanding that the government was far from the humanistic ideas of people's equality while opening specialized schools for the disabled in the XIX century. It was the utility, helpfulness of people that was of importance. In the first specialized schools foreign models of school practice and maintenance were introduced by foreign teachers [15]. It was likely the desire to imitate the western way of life in different spheres. That brings the historical peculiarity in developing inclusive education in Russia. There were no socio-cultural grounds to accept the necessity of education for people with disabilities. Practices introduced were alien to the Russian mentality. Moreover, those specialized schools were initially maintained by the sponsors, not the state.

An abrupt change in the socio-political structure of the state had a negative impact on the system of education. It particularly affected educating students with disabilities. Traditions of sponsorship and charity were interrupted; specialized schools were taken over by the people's Commissariat of Education (Narcompros). The state system of specialized correctional schools was being created. It was mainly based on boarding schools of the year-round staying. The organizational peculiarity in the developing education for people with disabilities is found in its extreme segregation. Boarding schools were isolated from the society. A system of quite specific relations in a segregated community was developing there. Later those relations passed on from the educational environment to the professional one $[16,17]$. It is worth mentioning that the problem indicated is also typical of other countries. For example, in Germany the real inclusion of people with disabilities in the labor communities is insufficient $[18,19]$. The disabled are excluded from employment in fact [20].

They are sometimes unable to cope with efficiency standards [21]. At the same time individualization of working hours and salary relation might support people with disabilities, improve quality of their lives [22]. Alongside numerous shortcomings, isolating people with peculiarities in their development [23] stimulated the development of defectology in Russia. Later it provided scientific and methodological grounds to shift from the segregated to the integrated education and further to the inclusive one.

The peculiarity of the content of education for people with disabilities is found in the so called qualifying education. It means students of specialized boarding schools had to be able to master the program, at the level suitable to continue education in the establishments of the primary and secondary vocational education. Such an approach had an ambivalent result. On the one hand students with minor disabilities were able to socialize through mastering profession [24]. On the other hand those with severe deviations were actually labeled uneducable and were even more isolated in the segregated educational system.

Socio-economic peculiarity in the development of inclusive education in Russia is also found out. Social, political and economic cataclysm in the early 1990s was followed by the proclamation of democratic values. At the political level, they were manifested through the ratification of some UN conventions. At the economic level it was the destruction of the established economic system. Hence, further development of inclusive education being an expensive project turned out impossible due to the bad economic crisis. The economic component of the problem was supplemented by the social one. Russian society was used to the isolation of the disabled. The Russians were unable to include people with disabilities in the society and to accept them being peers because of the lack of humanistic values. In Europe the natural process of the evolution of democratic society has lasted for hundreds of years. In Russia democracy is still young and crisis accompanying its establishment has not been overcome yet. Nevertheless educating people with disabilities for raising their living standard is a deep concern of the government.

Inclusion is not just a new trend in education. It is the basic essential principle of building a society, the philosophy of coexistence. The importance and the role of the environment should not be underestimated. Inclusive education is expected to change attitude of people and to form the basis for the legal, integrated and discrimination-free society. The 
result of implementing inclusive education is an individual who is both non-distanced and non-alienated from the society. However, practice shows that deep changes in the values of people are usually accompanied by numerous problems.

\section{Conclusion}

Social environment and social relations of an educational institution are changeable and dynamic. The characteristics of interpersonal relationships in the context of inclusion may cause additional difficulties of social adaptation for people with disabilities. In practice not inclusion and mutual assistance, but prejudice, mobbing and even mental and physical aggression are often observed. This creates an uncomfortable climate in the community, increased mental stress and leads to self-isolation and unwillingness to socialize. It involves another issue associated with the social position of people with disabilities - in their paternalistic attitude, in the "learned helplessness", in relying on people who are ready to solve all their life problems. The basis for successful life strategies of people with disabilities are in reducing this psychological addictiveness and developing such a trait as the ability of successful self-directed educational and productive activities [25].

The role of a teacher is of particular importance in solving this problem. In each pedagogical situation, the teacher determines the goal, chooses an adequate pedagogical tool, identifies it in accordance with educational tasks, and designs the class activities so that they meet both the qualification and inclusive goals at the same time [26]. Thus, the organization of mastering the competences directly depends on the didactic competence of the teachers, their readiness to ensure the formation of the basis for future activities.

Unfortunately, not all teachers are prepared to change their activities, often having neither practical experience of work with students with disabilities nor a full understanding of the methods of work with them. Accordingly, they experience fear, professional uncertainty and psychological lack of readiness to work with students with disabilities [27]. This requires integration of special training, the system of advanced training and retraining, as well as the availability of advisory services.

The following steps to solve the problems of inclusion in higher education are possible:

- progressive implementation of the local inclusive education policy;

- development of an effective scientific and methodological support system for students with disabilities in the system of higher education;

- development of the complex of methodological and technical support including useful teaching, information technology, technical and other educational tools for teaching students with disabilities, as well as an individual approach to training;

- ensuring a comfortable psychological environment in the educational process and creating conditions for social integration of people with disabilities through elaborate tactics of psychological support for all participants in the process of inclusive education;

- ensuring comprehensive system of training teachers for the implementation of inclusive education.

Thus, the solution of the problems of the implementing inclusion in higher education is in their rethinking and qualitative, systematic transformation. It is advisable to improve the working methods of administration and educational institutions in order to develop inclusive education and reinforce the rights of people with disabilities that will improve the living standard of the population in general.

\section{References}

1. G. Feuser, Inklusion - ein leeres Versprechen? Gießen: Psychosozial-Verlag (2017).

2. I. Schnell, Herausforderung Inklusion: Theoriebildung und Praxis. Bad Heilbrunn: Verlag Julius Klinkhardt (2015).

3. B.A. Rajzberg, L.Sh. Lozovskij, E.B. Starodubceva, The Contemporary Economic Dictionary. Moscow: INFRA-M (1999). [in Rus.].

4. S. Medcalfe, Economic well-being in U.S. Metropolitan Statistical Areas. Social Indicators Research, 139(3), 11471167. DOI: 10.1007/s11205-017-1755-5 (2018).

5. L. Beljaeva, Income inequality in Russian society: Social consequences and issues. Vestnik Instituta Sotziologii, 3(26), 83-100. DOI: 10.19181/vis.2018.26.3.526 (2018). [in Rus.].

6. United Nations, Convention of the Rights of Persons with Disabilities. Retrieved from: http://www.un.org/disabilities/documents/convention/convoptprot-e.pdf. Accessed: 06.02.2018 (2006).

7. United Nations, Sustainable Development Goals. Retrieved

from: https://www.un.org/sustainabledevelopment/education/. Accessed: 20.12.2018 (2015).

8. M.L. Agranovich, Achievements indicators for sustainable development goals in education and national education policies. Educational Issues, 4, 242-264 (2017). [in Rus.].

9. United Nations, United Nations Development Programme. Human Development Reports. Retrieved from: http://hdr.undp.org/en/faq-page/human-development-index-hdi. Accessed: 06.02.2018 (2018). 
10. K.-E. Ackermann, Zum Umgang mit Widersprüchen in der sonderpädagogischen Diskussion um Inklusion. In M. Gercke, S. Opalinski, T. Thonagel (Eds.). Inklusive Bildung und gesellschaftliche Exklusion (pp.229-247). Heidelberg: Springer (2017).

11. M. Carnoy, Ya.I. Kuzminov, Online-education: How it affects the university structure and economics. Yaroslav Kuzminov - Martin Carnoy panel discussion. Educational Policies, 3, 8-43. DOI: 10.17323/18149545-2015-3-8-43 (2015). [in Rus.].

12. P. Ashwin, Can the university education change a person? The tasks of mapping the transformative power of higher education in comparative studies on the education quality (translated from English by N. Udarova). Educational Issues, 1, 21-34. DOI: 10.17323/1814-9545-2016-1-21-34 (2016). [in Rus.].

13. N.N. Malofeev, Sponsors of schools for the deaf take a second breath. Defectology, 2, 52-62 (2004). [in Rus.].

14. N.N. Malofeev, Education for the blind in Russia of XIX century: Government and philanthropy. Defectology, 5, 74-82 (2004). [in Rus.].

15. E.N. Morgacheva, Foreign experience of inclusive education and the possibility of its use in native practice. Defectology, 3, 58-65 (2018). [in Rus.].

16. H. Fasching, Career counseling at school for placement in sheltered workshops? British Journal of Learning Disabilities, 42(1), 50-57 (2014).

17. J. Giesinger, Educational justice, segregated schooling and vocational education. Theory and Research in Education, 15(1), 88-102. DOI: 10.1177/1477878517696191 (2017).

18. M. Gebhardt, T. Tretter, S. Schwab, B. Gasteiger-Klicpera, The transition from school to the workplace for students with learning disabilities: Status quo and the efficiency of pre-vocational and vocational training schemes. European Journal of Special Needs Education, 26(4), 443-459. DOI: 10.1080/08856257.2011.597181 (2011).

19. T. Hoffmann, W. Jantzen, U. Stinkes, Empowerment und Exklusion: Zur Kritik der Mechanismen gesellschaftlicher Ausgrenzung. Gießen: Psychosozial Verlag (2018).

20. L. Simon, K. Clarke, Apprenticeships should work for women too! Education and Training, 58(6), 578-596. DOI: 10.1108/ET-02-2016-0022 (2016).

21. C. Belmonte, V. Suñé, The transition to working life plans. An inclusive training way for people with disabilities [Los planes de transicion al trabajo: Una opcion formative inclusive para personas con discapacidad]. Revista Espanola de Orientacion y Psicopedagogia, 25(2), 24-39 (2014).

22. L. Brown, K. Farrington, J. Suomi, M. Ziegler, Work-wage relationships and individuals with disabilities. Journal of Vocational Rehabilitation, 13(1), 5-13 (1999).

23. S. Tomlinson, Social justice and lower attainers in a global knowledge economy. Social Inclusion, 1(2), $102-112$. DOI: 10.12924/si2013.01020102 (2013).

24. P.R. Egorov, Historical periods in the development of the ideas of educating people with sight disabilities. Science and Education, 2(58), 48-51 (2010). [in Rus.].

25. Yu.P. Sheyn, L.P. Sheyna, Problems of inclusion and social success of people with disabilities. Vestnik UGUES., 3(13), 44-48 (2015). [in Rus.].

26. I. Hedderich, J. Hollenweger, G. Biewer, R. Markowetz, Handbuch Inklusion und Sonderpädagogik. Bad Heilbrunn: Verlag Julius Klinkhardt (2016).

27. U. Heimlich, Inklusive Pädagogik: Taschenbuch. Stuttgart: Kohlhammer W., GmbH (2018). 